\title{
Origin of the holothurians (Echinodermata) derived by constructional morphology
}

\author{
Reimund Haude ${ }^{1}$ \\ With 4 figures and 1 plate
}

\begin{abstract}
According to a recent hypothesis, the holothurians originated by a process of extreme paedomorphism as "giant larvae", with "de novo" developed radial systems. However, the present approach, which follows the principles of constructional morphology, supports former views that the holothurian predecessor must have been echinoid-like. After constitution of a (reliable) early predecessor construction as a model with machine analogies, subsequent steps of structural transformation are explained by functional improvement and economy. Following results are discussed: (i) Holothurians have to be derived from a postlarval precursor; (ii) "Apodida" (as molecular-genetically derived first holothurians) must originally have been pedate; (iii) ophiocistioids would not be cladistic "holothurians" but a precursor construction of the taxon echinoids plus holothurians; (iv) the Lovenian structure of the calcareous ring of Nudicorona (Middle Devonian), possible radial series in Palaeocucumaria (Lower Devonian), and distribution of the podia in two new holothurian body fossils from the Lower and Middle Devonian (preliminary description as Prokrustia tabulifera n. gen., n. sp. and Podolepithuria walliseri n. gen., n. sp.) obviously corroborate homology of holothurian and other echinoderm radial systems; (v) different extent of podial and body wall skeletonization suggests the existence of respiratory trees by no later than the Middle Devonian.
\end{abstract}

Key words: Holothurians, evolution, constructional morphology, new taxa, Devonian.

\section{Zusammenfassung}

Nach einer neueren Erklärung, die sich auf eine Theorie zur Homologisierung von larvalen und adulten Strukturen von Echinodermen stützt, sollen die Holothurien über extreme Paedomorphose, d.h. über „Riesen-Larven“ mit neugebildeten postoralen Radial-Systemen entstanden sein. Dagegen läßt sich anhand eines konstruktions-morphologischen Verfahrens zeigen, daß Holothurien auf einen Echiniden-artigen Vorläufer zurückzuführen sind. So wird zunächst eine (wahrscheinliche) frühe Vorläufer-Konstruktion der Echinozoen nach Maschinen-Analogien konstituiert. Die daran anschließenden strukturellen Transformationen werden nach funktionellen und energetischen Kriterien begründet. Sie führen zwanglos zu Konstruktionen, die nicht nur rezenten Formen entsprechen, sondern offensichtlich auch durch bekannte und neue paläozoische Fossilien bestätigt werden. Im Einzelnen werden folgende Ergebnisse zur Diskussion gestellt: (i) Holothurien sind von einer post-larvalen Vorläufer-Konstruktion abzuleiten; (ii) die füßchenlosen „Apodida“ (als molekulargenetisch früheste Holothurien) müssen zunächst vollständige Radien mit Podia besessen haben; (iii) bei den (nur paläozoischen) Ophiocistioiden handelt es sich nicht kladistisch um „Holothurien“, sondern sie repräsentieren eine Vorläufer-Konstruktion des Taxons Echiniden plus Holothurien; (iv) die Loven'sche Struktur des Schlundrings von Nudicorona (Mittel-Devon), die möglicherweise radialen Strukturen bei Palaeocucumaria (Unter-Devon) und die Verteilung der Podia in zwei neuen, vollständig erhaltenen Holothurien aus dem Unter- und Mittel-Devon (vorläufige Beschreibung als Prokrustia tabulifera n. gen., n. sp. und Podolepithuria walliseri n. gen., n. sp.) stützen die konstruktions-morphologische Begründung der Homologie der Radial-Systeme bei Holothurien und den übrigen Echinodermen; (v) das deutlich unterschiedliche Ausmaß der Skelettierung von Podia bei den neuen HolothurienFunden scheint anzudeuten, daß die analen Respirations-Strukturen der Holothurien spätestens ab dem Mittel-Devon vorhanden sind.

Schlüsselworte: Holothurien, Evolution, Konstruktions-Morphologie, neue Taxa, Devon.

\section{Introduction}

Worm-like form and extreme reduction of the body wall skeleton makes holothurians the most atypical of echinoderms. Their origin, therefore, is controversial (e.g., Ludwig 1889-1892, Be- cher 1908, Smiley 1988). In early studies, certain larval stages were thought to be particularly significant (and formed the basis of farreaching phylogenetic speculations, e.g. those of Semon 1888); later, larval development lost its appeal (e.g., Strathmann 1975). Other hypoth-

1 Geowissenschaftliches Zentrum der Universität Göttingen (GZG), Abt. Geobiologie, Goldschmidt-Str. 3, D-37077 Göttingen, Germany.

Received March, accepted July 2002 
eses on the origin of holothurians include derivation from edrioasteroid-, ophiocistioid-, and echinoid-like ancestors (e.g., Fell 1965, Pawson 1966, Smith 1988, Haude 1995a). Palaeozoic body fossils of holothurians as possible direct witnesses of the early evolutionary history were either misidentified (Cambrian Eldonia, Ordovician Eothuria), missing (in the Ordovician and Silurian) or extremely rare (Early to Middle Devonian).

In recent years, two fields of investigation treat holothurian origin: (i) According to certain molecular genetic studies, the echinoids and holothurians are the sister group of the asterozoans, and the first holothurians belong to either the "Elasipoda" (i.e. pedates) or, with better support, to the "Apodida" (i.e. impedates) (Littlewood et al. 1997, Smith 1997, Kerr \& Kim 1999, 2001). (ii) A new concept in comparative morphology of echinoderms, the extraxial axial theory (EAT; David \& Mooi 1996, Mooi et al. 1994, et sequ.), allows identification of homologies in comparison of larval or juvenile and adult stages, thus separating characters that might have evolved during one or another stage; observations on indirect development of planktotrophic (feeding) larvae (e.g., Selenka 1876, Semon 1888, Clark 1898, Edwards 1909, Runnström 1928, Smiley 1986) regain high importance. According to this theory, most of the holothurian body would be of larval origin.

However, from the point of view of constructional morphology, there are reservations against phylogenetic explanations based on current procedures of comparative morphology, because (i) character statistics are presented as the only reliable scientific fundament; (ii) belief in sequencing data reflects hope that regulator gene analysis would solve morphological problems (David \& Mooi 1998); and (iii) by ignoring the physical conditions of change in organismic architecture, the causal explanation of phylogenetic transformation is deliberately restricted (for discussion see, e.g., Gutmann 1994, 1995).

An earlier attempt to explain the origin of holothurians by constructional morphology (Haude 1995a) was mistaken in part because the inferred process of incorporating pre-echinozoan radial vessels into vertebra-like (ophiuroid) ossicles is incorrect, and because important structural-functional parameters in the developmental processes of the planktotrophic larva were ignored.

The following considerations will focus (i) on some critical points in recent interpretations of larval morphologies; (ii) on a structural-functional explanation of evolutionary transformations in echinozoans and holothurians; and (iii) on interpretation of some structures of old and new discoveries of Palaeozoic body fossils, among these two new holothurians, here provisionally described in the Appendix.

\section{Some relevant larval structures}

During ontogeny of holothurians with feeding larvae, the well-adapted planktonic larval and benthonic juvenile/adult "Bauplan" passes transitory stages of weak adaptation. Such stages of minor ecological fitness would show less structural control against genetically driven changes (e.g., in larvae, Wray \& Lowe 2000; or generally to be expected in juvenile stages, Edlinger 1994). Therefore, transitory development had to be optimized by evolutionary shortening, i.e. by metamorphosis (Bonik et al. 1979, and others).

If compared among early life histories of different eleutherozoans (e.g., Smith 1997), metamorphic change in planktotrophic larvae of holothurians is quite insignificant. Larval structures, e.g. body wall, digestive tract and bilateral symmetry persist into juvenile and adult morphology. Such an obviously paedomorphic development (Smiley 1986, Smith 1988) was taken as evidence of an origin of the holothurians as "giant larvae" (David \& Mooi 1998: 24).

In non-holothurian eleutherozoans, the five primary (radial) tentacles will become the terminal ones, i.e. the tips of the elongating radial canals advance with the ocular plate in front of the series of newly forming ambulacral plates (ocular plate rule, OPR, of David and Mooi). In the late feeding larva of holothurians, however, the primary tentacles remain in an adoral position and the hydrocoelic canals are budded in-between the juxtaposed bases of the primary tentacles. Such an interradial position would suggest non-homology with the radial canals of other echinoderms (Semon 1888; for an early discussion of problematical adoral hydrocoelic developments see e.g., Ludwig 1891, Clark 1898, Becher 1907). Protrusion within the body is without contact to epidermal structures (Smiley 1986). Subsequent irregular formation of podia in juvenile pedates (Selenka 1876, Edwards 1909) is not in accordance with the OPR. The hydrocoelic canals of holothurians were thus interpreted by David \& Mooi (1996) as secondarily formed. 


\section{Bauplan transformation by constructional morphology}

Development of organismic architecture is not only determined by genetic processes but is highly subjected to morphodynamics, i.e. to antagonistic and changing physical processes. The same is true for the development in evolving constructions. Hence, they all depend on transformation and canalization of energy. Phylogenetic reconstruction of a biological "Bauplan", therefore, has to be related to its machine-like functioning. By constituting a model in using analogies with a machine, it should be possible to identify the relevant physical laws of such a construction and, if possible, available subsystems (e.g., physiology). Hence, not only the structural and physical preconditions of a given architecture should be explainable, but also those of potential subsequent transformations by taking into account aspects of energy balance, i.e. criteria of optimization and economy (Bonik et al. 1977, Edlinger 1994, Gutmann 1994; for recent overviews of the methodology of this "Frankfurt theory", its fundament within theory of science, examples of practical application, and further literature, see Janich \& Weingarten [1999: 212-216], Gudo [2001: 20-29], and Grasshoff \& Gudo [2001]).

\section{The echinozoan construction and some prerequisites for structural transformation}

A precursor construction of the echinozoans may be derived from crinozoans in being radiate but feeding oral-side-down. It may have been a short-armed asteroid-like construction, but with a relatively large disc to contain a long (looped) gut.

This construction is constituted as a model with machine analogies by several interrelated technical and geometric parameters: (i) bearing capacity of the external hydraulic projections (podia); (ii) imbrication at plate contacts of the body wall skeleton (allowing shifting movements and flexibility in horizontal and vertical directions); (iii) radial and circular contractile tissues in the body wall (for, e.g. height and width control of the disc); (iv) adoral hydrostatic cushions (by ventral protrusions of the adoral [left] metacoel) supporting opening and closing mechanics of the mouth; (v) radial lacunar devices by juxtapositioning of elongated metacoelic protrusions with the hydrocoelic canals (for physiologically providing the requirements for activated radial structures like longitudinal muscles and hydraulic projections [podia]).

Evolutionary transformation in the direction of an echinozoan construction is explained as structural-functional change of such parameters by considering aspects of optimization and economy:

1. Enlargement of the hydraulic projections (podia) and skeletal support of their wall for increase of bearing efficiency.

2. Alternative feeding mechanics by, either, more or less horizontally directed opening and closing movements of oral series of skeletal elements (with potential frontal pressing touch of opposing series); or, more vertically directed movements of the perioral body wall (without frontal pressing contacts). The first method would develop in direction of an asteroid construction. The latter process would suggest development in the echinozoan direction: Invaginatory mechanics are optimized by separation of the metacoelic protrusions as hydrostatic cushions by means of strings or sheets of (mesenteric) tissues, thus serving as antagonists for muscular activity (Fig. 1A).

3. Relative enlargement of the body (disc) with distal incorporation of the arms (analogous in form to some fossil and recent globular but short-gut asterozoan constructions, see Blake 1984): Invaginatory ingestion of substrate-derived food must have triggered optimization of digestive capacities by, e.g. further elongation and enlargement of the gut; this, in turn, increased the body volume.

4. Perradial shifting of the external radial canal inward-and-below the imbricating biserial ambulacral plates (Fig. 1B, C) (with the probable exception of invaginated first plate [or plates?], Fig. 1C, arrow): Thus, the considerably increased risk of injury by facultatively extreme adoral exposition of ambulacral organs during invaginatory feeding activity would be minimized.

5. Exclusion of the ring canal from adoral deformational processes resulting in circular outline. Due to the invaginatory processes the ring canal is raised into suspension within the metacoel (thus losing a probable sinusoidal form which is caused, e.g. in the asterozoans, by direct contact with the adoral ossicles). 


\section{Lines of transformation}

\section{in the echinozoan construction}

By mechanical specialisation of invaginated adoral skeletal elements for feeding, a semiautonomous apparatus (lantern) would be developed. The vaulted but still relatively depressed form of the disc would still be asterozoan-like dorsally as can be deduced from geopetal biostratinomic orientation of Middle Devonian ophiocistioids (Haude, unpublished observations).

Several other structural-functional options are realized before development of a more efficient echinoid feeding apparatus. Dorsal functions of the body wall are optimized by relative prolongation of the radial organs. This would be attained by termination of growth and thus narrowing of the dorsal (extraxial, ophiocistioidanrelated) part of the body wall. There are two subsequent structural alternatives: the first is formation of a solid wall without retention of contractional functions (e.g., in the bothriocidarids, with later development of a lantern-like feeding apparatus); the second is facultative vaulting by muscular activity of the body wall (in an echinoid-like construction, with later development of an efficient lantern). From the structural-functional level of a vaulting potential, further optimization of certain structures is thought to be a realistic option for reaching the level of the holothurian construction.

\section{Structural changes as prerequisites of the holothurian body construction}

1. Optimization of the invaginatory movements of adoral parts of the body wall must lead to rotation of the very first radial plate (or plates?) into an almost inverse position, yet with the contiguous part of radial canal still lying on the original "outer" side (Fig. 1A). Hence, the first radial(s?) (Fig. 1D, arrow) would become geometrically separated from the succeeding series of plates, which came to lie externally by the already mentioned submerging process of the radial canal (Figs 1B, C). Such a separation is perceived as a structural-functional precondition for transformation of radial plates into elements of the holothurian calcareous ring.

2. In a vaulted and unrayed body skeletonized with imbricating plates, flexure of the wall (with resulting variation of height and dia- meter of the body) would be accomplished by antagonistic contraction of longitudinal and circular muscles. Increase of height (i.e. an oral-aboral elongation) would destabilize a mouth-down orientation of the body, leading to a more or less inclined and recumbent position.

3. Feeding could now be performed only by activity of adoral hydraulic projections ([podia] thus impeding evolution of a mouth skeleton). Therefore, such mechanisms would be optimized by concentration, enlargement, or other kinds of differentiation of these structures.

4. Body wall activity (favourably for increase of height, i.e. elongation) would be optimized by reduction of skeletal plates. Hence, "skeletal guidance" for the terminal tentacles (= tip of

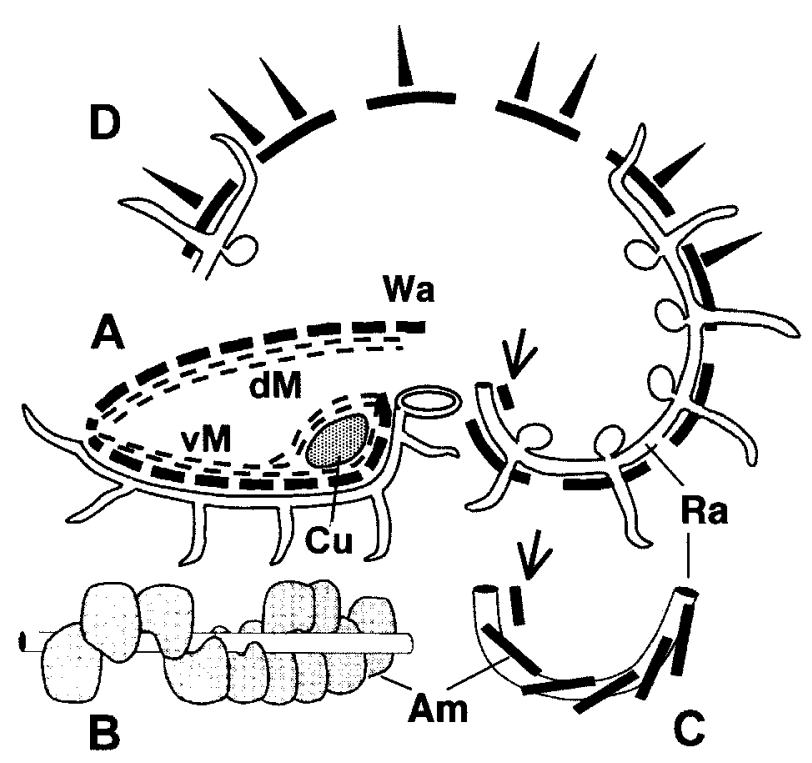

Fig. 1. Model of parts of the soft body architecture in the precursor construction of holothurians. A. Section along an ambulacral furrow (with external radial canal) in an unrayed ("Culcita-like") asterozoan construction with large extra-axial dorsal area; radial muscles hypothesized as not only dorsal, but also meridionally-ventral; vertically directed adoral activity for feeding facilitated by protrusion and mesenteric separation of a part of the left metacoel, thus serving as an energy-saving hydraulic cushion. B. Detail of process of inwardshifting of the radial canal perradially below imbricating ambulacrals, beginning somewhere below the invaginated adoral part (right). C. The facultatively invaginated part in cross section showing the inward-shifting of the radial canal (except the most internal first ambulacral plate[s], see arrow). D. Section along a "left/right" radius in an already more vaulted echinoid-like construction (spines) with internal radial canals and a still relatively large extra-axial dorsal area, the ventral area (without spines) may signify also an ophiocistioid-like precursor (the dorsal wall of which would correspond to that of the "Culcita-like" type). Arrows, indicating first ambulacral plate in original ("internal") position; Am, ambulacral plates; Cu, coelomic cushion (shaded); Ra, radial canal, vM/ dM, ventral radial (meridional)/dorsal radial muscle (thin dashed lines); Wa, flexible body wall with skeletal plates (thick dashed lines). 
radial canals) would be lost (i.e. there is no more going ahead according to the OPR of a terminal plate beyond serially added ambulacrals).

5. Associated with skeletal reduction would be increase of energy-saving mutable collagens in the body wall.

6. Without "skeletal guidance" (i.e. without further addition of ambulacral plates), the epidermal contact of the radial canal (corresponding to the terminal tentacle) is no longer necessary. Prolongation of the radial canal, therefore, must proceed through increased genetic control. With reduced external constraints, radial growth and budding of podia must become more irregular.

7. Geometrically limited space between the functionally enlarging basal part of the feeding tentacles would stimulate some relative lateral shift among the tentacles and radial canals, the latter emerging at the topographic "fixing points" of the originally first radial elements.

8. Recumbent life position would favour specialization of, e.g. ventral and dorsal podia; thus, further differentiation including bilateral symmetry is initiated.

9. Correspondence of larval, juvenile, and adult functional form (elongate and bilaterally symmetrical) would allow optimization of developmental transition by reduction of complicated processes of metamorphosis.

\section{Evidence from some old and new fossil discoveries}

Ophiocistioids: These Palaeozoic echinozoans have a more or less vaulted (yet not globular) disk with only ventral radii of two rows of more or less alternating large and strong podia that are well skeletonized by imbricating plates, internal radial canals and an echinoid-like lantern. The body wall is either strongly skeletonized by large plates (Ubaghs 1966, Jell 1983), or it contained only holothurian-like microscopic deposits plus a perradial row of either bilaterally symmetrical or slightly alternating ossicles (Haude \& Langenstrassen 1976). The upper (dorsal) part of the disc would correspond to the extraxial dorsal part of a "Culcita-like" asterozoan construction (Fig. 1A, in having, e.g., no considerable dorsal prolongation of radial organs). They must have had a coiled gut with a dorsolaterally located anal opening.
Echinoids: The corona of imbricating plates of early fossil echinoids (Upper Ordovician Ectinechinus and Eothuria) is postmortally (biostratinomically) elongate-globular (MacBride \& Spencer 1938). This egg-like form resulted from antagonistic activity of muscular (and mutable collagenous) tissues of the body wall that must have served for hydraulic support of protraction and retraction of the quasi-autonomous oral skeleton (lantern). The almost perradial alignment of hydrocoelic pores in the ambulacral plates supports the interpretation (e.g., by Jackson 1912) of a shifting process of the radial vessels in-between and below the imbricating plates (Figs 1B, C).

Holothurians: First unequivocal remnants of holothurians are sclerites (and possible ring elements) from the Middle Ordovician (Reich 1999). Early body fossils are rather late, from the (?)uppermost Silurian (Gilliland 1993) to the Middle Devonian. They are well skeletonized (and therefore fossilized, probably in contrast to unknown Ordovician representatives). The one (?)uppermost Silurian (Pridolian) specimen had been assumed to be quite similar to the Lower Devonian (Emsian) Andenothyone, which has an imbricate body wall skeleton (Haude 1995b). The former might have "perforated plates" (Gil-

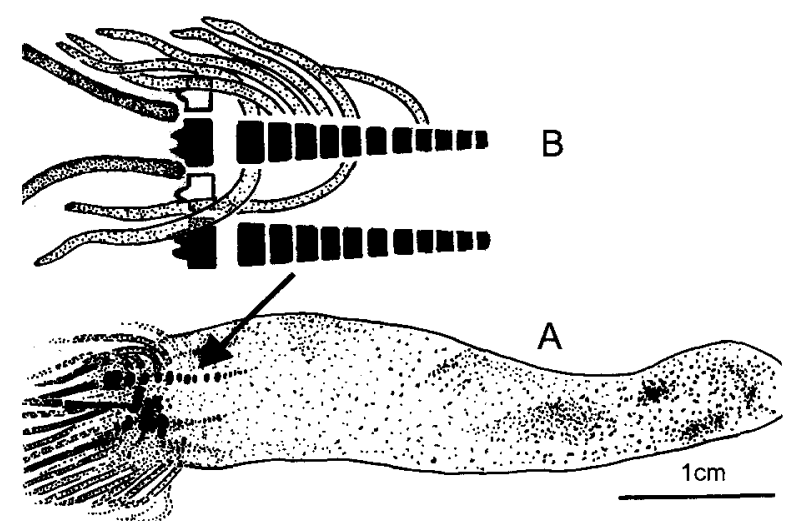

Fig. 2. Palaeocucumaria hunsrueckiana (traced from X-ray photo in Bartels et al. 1997: fig. 60). A. Podia obviously arranged in radial lobes. At least one short adoral row of ossicles possibly signifying vestigial ambulacrals. Larger skeletal elements in the adoral center suggest an autochthonic (noneviscerated) calcareous ring. A few frontal podia showing a bit darker shadowing (i.e. denser skeletonization) may indicate specialized tentacles. B. Details of two hypothetical ambulacral rows with some podia. The first (larger) element in a row interpreted here as radial ring element (but morphologically distinct from three-winged radials in "eviscerated rings" of those associations of Palaeocucumaria [in Seilacher 1961, Bartels et al. 1998]). The (hypothetical) structure of the first element would give passage for a radial canal between two frontal processes and bear two lateral (?specialized) tentacles. 
liland 1993: 64), which are not observed in the latter.

The Lower Devonian Palaeocucumaria is especially noteworthy because (i) of its skeletonized podia or tentacles at the oral end; (ii) the podia may be arranged in short radial lobes (Fig. 2A; see also Smith 1988: fig. 7.4); (iii) of the occurrence in groups of several specimens (Fig. 3A); (iv) of a (presumed) earliest known occurrence of the evisceration process which is typical behaviour of some holothurians (Seilacher 1961; the inference was based on a group of specimens associated with several calcareous rings, Fig. 3A); (v) of adoral longitudinal rows of ossicles (according to specimen of Fig. 2A), which could represent vestigial ambulacrals (hitherto only the one or two observed, and the only ones in this specimen).

The ambulacral nature of the one row of ossicles would be corroborated by, probably, two of the podia of a podial lobe taking their origin at two of those ossicles (Fig. 2B). (An interpretation of the row structure as a stone canal is unlikely - even if the assumption of Bartels et al. [1998] was right that a larger adoral plate is the madreporite because, on the one hand, the row is apparently extending too far to take its origin at the hydrocoelic ring; secondly, the obviously uniserial structure of the row would be unique for stone canal ossicles.)

There are further curiosities with Palaeocucumaria: (i) The more prominent adoral shadows in Figures 2A, 3A suggest the existence of noneviscerated rings (according to the original interpretation of Lehmann 1958); (ii) the structure of the associated "eviscerated" rings (Fig. 3A), some of them with probably three frontal projections (Fig. 3B, similar to the Lower Devonian radial piece in Prokop 1993), would suggest the former existence, beside a radial canal, of about three specialized oral tentacles per ray (i.e. in total fifteen); (iii) there are, however, a bit darker podial shadows which may signify the existence of only a few more specialized, possibly more densely skeletonized tentacular podia; (iv) the "eviscerated" rings may belong to another (unskeletonized) holothurian, the possible existence of which was conjectured by Kutscher \& Sieverts-Doreck (1977).

The question bith regard tothe nature of the calcareous ring of $P$. hunsrueckiana (or of those rings associated with several specimens of $P$. hunsrueckiana) also concerns (i) forms like the Middle Devonian unskeletonized Nudicorona (Haude 1995a, 1997), and early Eifelian scleritomes like
Achistrum tuto Boczarowski (2001), which may have been as poorly skeletonized as the Pennsylvanian "Achistrum n.sp." (Sroka 1988): they would be not visible in $\mathrm{x}$-ray photos; (ii) the excellently preserved and rich material of scleritomes of $\mathrm{Pa}$ laeocucumaria ancile and delicata (see Boczarowski 2001), which has not delivered any of those very typical and compact elements of the ring (Fig. 3B, according to Seilacher belonging to $P$. hunsrueckiana, see above). Would these observations suggest premortal loss (i.e. by evisceration prior to sedimentation)? Or are the radials in $P$. hunsrueckiana of a segmented type as in some dendrochirotids, thus not being preserved by disintegrative preparation?

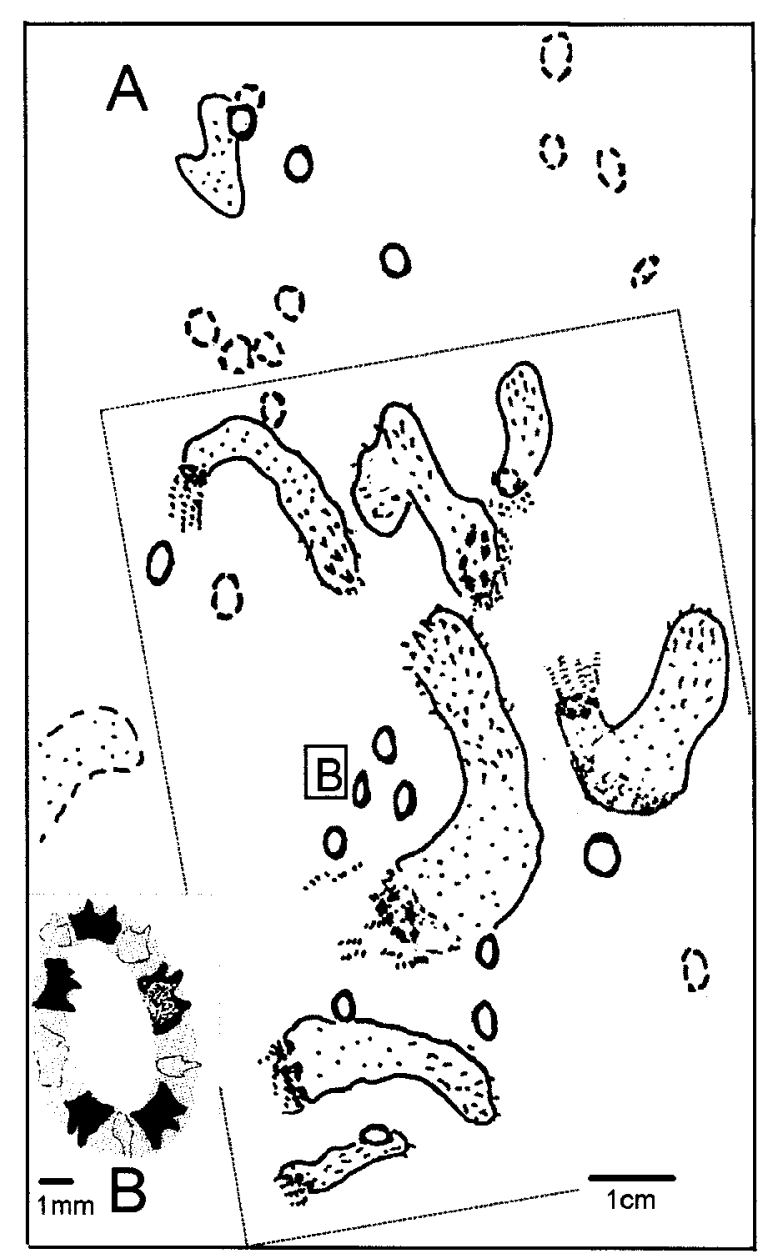

Fig. 3. A. Several specimens of Palaeocucumaria hunsruekkiana and calcareous rings (traced from X-ray photo of piece of Lower Devonian Hunsrück slate (large frame) containing the original of Seilacher 1961: fig. 1 (smaller frame); full rings indicate specimens visible on the prepared surface of the slate, dashed rings only visible by $\mathrm{x}$-ray photo), frontal part of holothurians (with indicated tentacles / podia) showing shadows of larger ossicles discussed in the text as possible non-eviscerated rings. B. Sketch of calcareous ring (specimen B in Fig. 3A, traced from $x$-ray photo in Haude 1995a: fig. 2B); despite rather bad micro-preservation, the one or other of the radials (black) may suggest the presence of three frontal projections. 


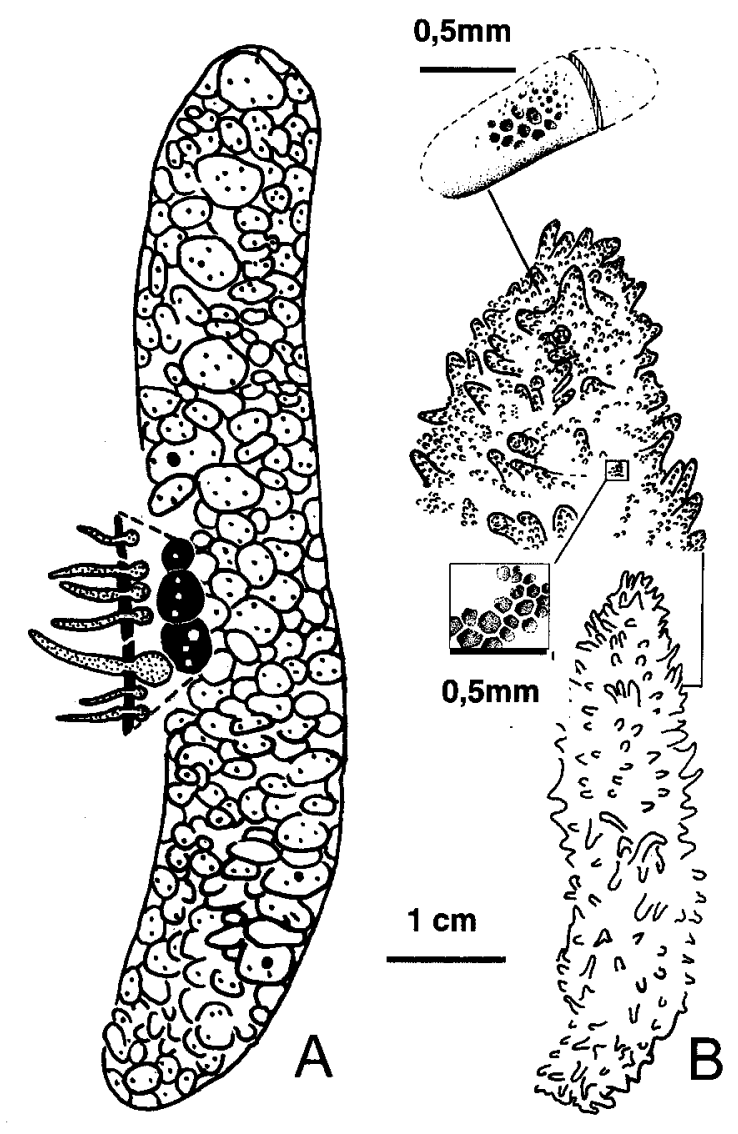

Fig. 4. Palaeozoic pedate holothurians. A. Lower Devonian Prokrustia (diagrammatic) (see Pl. 1: 1-3), thick plates of the body wall skeleton, most with about three to four small pores, some with a large pore; black plates sectioned to show hypothetic unskeletonized podia. B. Middle Devonian Podolepithuria (see Pl. 1: 4-5), small specimen (GZG 1123-3), upper part enlarged, body wall with small ellipsoidal (detail) and sieve plates (detail of stereomic structure), podia densely skeletonized with scale-like sclerites.

The ring of Nudicorona is basically asymmetric in showing a Lovenian $\mathrm{AABAB}$ configuration of the radials. This would correspond to the arrangement of first ambulacrals of the rays in other eleutherozoans (Hotchkiss 1995, 1998). Hence, each holothurian radial would represent the first and only persisting element of reduced rows of uniserial ambulacrals (Haude 1994).

Podial structures along the body are found in new Lower to Middle Devonian holothurians (Fig. 4) and, possibly, already in the (?)Upper Silurian specimen. They are distributed all around the skeletonized body: In the relatively gigantic Lower Devonian Prokrustia (Fig. 4A; for a preliminary description, see the Appendix), most of the rather thick rounded plates have one to several pores of differing diameter; these are interpreted as hydrocoelic structures, i.e. as canals of unskeletonized podia (with respiratory potential). On the other hand, skeletonized Middle Devonian holothurians, e.g. Podolepithuria, do clearly have podia which are densely skeletonized by microscopic uni- and multilayered sclerites (Fig. 4B; for a preliminary description, see the Appendix).

\section{Discussion}

During metamorphosis of recent planktotrophic larvae, only a few segments of important developmental stages would mirror evolutionary divergence in the higher taxonomic groups. Such stages must still have maintained vestigial structures, e.g. the original mouth before having to evolve a secondary one, finally expressed by a rudiment as developmental shortening of ontogeny. Planktotrophic larvae of holothurians are only known in (Recent) aspidochirotes and apodids. According to sequencing results, both groups are phyletically quite distant from a holothurian origin, the aspidochirotes in a topologically higher position (and, according to Kerr \& Kim [2001], rather late in the Palaeozoic, but with regard to the body fossils discussed above possibly already present in the Middle Devonian). The synaptids are sequentially rather young, yet within the topology of Apodida belonging to the basal branch (Kerr 2001). In constructional morphological terms, however, this branch is maintained as primarily pedate.

When attaining a globular form with a flexible skeleton, one structural-functional option would concern an optimization of facultative stretching activities of the body (by muscular and mutable collagenous tissues). This must have been accompanied by reduction of skeletal plates. The result of such a development in a "first holothurian" would somehow correspond in its elongated form and bilateral symmetry to transitory stages of the late feeding larva into the juvenile holothurian. With evolutionary truncation of development, therefore, neither a complicated change of metamorphosis nor a radical change of tissues was necessary during transition into the adult construction. Hence, the argument of paedomorphosis would be superfluous.

With progressive skeletal reduction, no series of (ambulacral) plates would be left for a mechanistic OPR-controlled translation (i.e. pushing on by serial addition of skeletal plates), in meridional direction, of the tip of the radial canal. An adult body wall without plates, therefore, cannot be analysed by means of the EAT; hence, in that case an interpretation as larval-extraxial would be senseless. 
According to David \& Mooi (1998: 24), the originally radial tentacles are shifting laterally into an "interradial" position later in ontogeny, where they associate with the bases of the "de novo-formed" "interradial" canals (which were interpreted, therefore, by Mooi \& David [1997] as not-homologous with the radial systems of other echinoderms). However, the meridionally extended radial organs of the globular progenitor retained their functional importance even after skeletal reduction. They would be expressed, therefore, at the same (relatively) radial position which is indicated by the single persisting first formed plate of the ancestral ambulacral series, i.e. the radial element of the calcareous ring. (For discussion on relativity of positions of buccal tentacles, see Runnström 1928, Dawydoff 1948, Hotchkiss 1998.)

According to constructional morphology, the early body fossils without aboral podial structures must be secondarily impedate. (It is left open whether they belong into the evolutionary line of skeletonized "Apodida"; but it is most questionable to interpret them as dendrochirotids as had been tentatively suggested for the Lower Devonian Andenothyone by Haude 1995b.) Loss of podia may be deduced from (i) those short ambulacral lobes in Palaeocucumaria (Fig. 2) which would signify a pre-final stage of podial reduction (but not of all other organs of the radial system); (ii) the transient appearance of late larval to early juvenile radial canals in some synaptids (Ludwig 1891); and (iii) the persistence of other radial organs (longitudinal muscle, radial nerve and hyponeural canal) in adult synaptids (e.g., Becher 1907, Clark 1907).

Hence, assignment of Palaeozoic holothurians (formerly only spicule-based higher taxa [e.g., Frizzel \& Exline 1955, 1966, Deflandre-Rigaud 1962, Gilliland 1993] but meanwhile also scleritome-based [Boczarowski 2001]) to recent higher taxa may be in need of considerable discussion since many other echinoderm groups had been either eliminated at the end of the Palaeozoic, or because well-known Mesozoic to Recent echinoderm groups are different from related Palaeozoic taxa.

With their "giant-larva"-hypothesis, David and Mooi are implying processes of regulatory genetics (acting in the mentioned transitional stages of weak adaptation). In discussions on comparative morphology, such processes are used as dii ex machina, either directly or combined with hypotheses on macroevolutionary mechanisms (e.g., by preadaptation in the model of "correlated progression", Thomson 1992). However, though all such ideas may be quite plausible, they do not help in step-by-step evolutionary reconstruction.

According to fossil evidence, arguments of constructional morphology would find some corroboration, e.g. by ophiocistioids, in that (i) their dorsal part is not homologous with the aboral region of apodans; (ii) reduction of skeletal plates, i.e. evolutionary development of sieve and wheel sclerites in the body wall, is not directly related to similar developments in holothurians; (iii) the submerging process of the meridional (radial) organs to below the ambulacral plates must have been accomplished before the beginning of a relative prolongation of the radial systems in the dorsal part.

The Devonian age of the pedate holothurians may appear as rather late to be of much concern for understanding the origin of holothurians. However, it may give a possible first date for the evolution of "cloacal" (respiratory) trees, which, in recent holothurians, may provide about half needed oxygen (Hyman 1955, Smiley 1994). In a large and heavily skeletonized form like the Lower Devonian Prokrustia, with unskeletonized respiratory podia, "cloacal" evaginations may not have evolved yet. (For physical reasons, forms with a small diameter like Lower Devonian skeletonized impedates did not require internal respiratory structures.) However, in relatively large Middle Devonian holothurians, dense skeletonization of the podia may suggest less aptness for podial respiration. Hence, "cloacal" respiratory evagination could have been achieved, at least in the late Lower Devonian, by dendrochirotid or skeletonized (?)aspidochirotid forms.

\section{Conclusions}

1. Ontogenetic development without radical morphological change (metamorphosis), from the feeding larva into the adult, would result from confluence of evolutionary shortened adult form with corresponding larval structures.

2. An explanation of the origin of holothurians by paedomorphosis and homeotic transfer of radial organs therefore appears unnecessary.

3. With arguments of constructional morphology, holothurian architecture can be derived from juvenile / adult morphology of a globular ancestor with an actively deformable body wall skeleton of imbricating plates. 
4. According to this hypothesis, body wall activities were only possible after development of meridionally completely extended radial systems for mechanical and physiological support.

5. Therefore, the "Apodida" as the phyletically earliest group (according to sequencing data), must have comprised pedate forms as first representatives, thus indicating that there may be a taxonomic confounding with the pedate "elasipods" as the next phyletic branch.

6. This hypothesis may be supported, in part, by the Lower Devonian "apodid-like" Palaeocucumaria.

7. Large Devonian pedates with densely or heavily skeletonized body walls ("dendrochirotids" or skeletonized "aspidochirotids") may suggest that "cloacal" respiration (by respiratory trees) had already evolved, at the latest, in the Middle Devonian.

\section{Acknowledgements}

My interest in constructional morphology of the Frankfurtian kind was raised significantly by ardent phylogenetic discussions with Hans-Peter Schultze, about 25 years ago, before he left Göttingen for Lawrence, Kansas. In his criticism of this approach on constructions as unduly speculative, he (a protagonist of the Hennigian methodology on morphological characters) motivated me - yet, probably, quite unwillingly - to be prepared for defending it. Hence, the present "origin of holothurians" is directly or indirectly indebted to his efforts.

I am also most grateful for the help which I received from several individuals: G. Kronholz (Münster) produced microradiographs. Michael Gudo (Frankfurt) gave support on constructional morphology in an earlier version of the manuscript. Daniel B. Blake (Urbana) and Wolf-E. Reif (Tübingen) critically reviewed the manuscript; especially the former made many incisive (and uncomfortable) comments leading to more clarity of the views presented. Daniel Haude and Jim Lacy (Hamburg) corrected the final version.

\section{References}

Bartels, C., Lutz, H., Blind, W. \& Opel, A. 1997. Schatzkammer Dachschiefer: Die Lebenswelt des HunsrückschieferMeeres. - 82 pp. Landessammlung für Naturkunde Rheinland-Pfalz und Deutsches Bergbau-Museum Bochum, Mainz u. Bochum.

Bartels, C., Briggs, D. E. G. \& Brassel, G. 1998. The fossils of the Hunsrück Slate. Marine life in the Devonian. - Cambridge Paleobiology Series 3: I-IV, 1-309. Cambridge University Press, Cambridge, New York, Melbourne.

Becher, S. 1907. Rhabdomolgus ruber Keferstein und die Stammform der Holothurien. - Zeitschrift für Wissenschaftliche Zoologie 88: 545-689.

- 1908. Die Stammesgeschichte der Seewalzen. Habil. Schrift, Giessen. - Ergebnisse und Fortschritte der Zoologie 1: 1-88.

Blake, D. B. 1984. Constructional morphology and life habits of the Jurassic sea star Sphaeraster Quenstedt. - Neues Jahrbuch für Geologie und Paläontologie, Abhandlungen 169: $74-101$.
Boczarowski, A. 2001. Isolated sclerites of Devonian non-pelmatozoan echinoderms. - Palaeontologia Polonica 59: $219 \mathrm{pp}$.

Bonik, K., Grasshoff, M. \& Gutmann, W. F. 1979. Die Evolution von Larven als Verbreitungsstadien bodenlebender Meerestiere. - Natur und Museum 109: 70-79.

Bonik, K. \& Gutmann, W. F. \& Peters, D. S. 1977. Optimierung und Ökonomisierung im Kontext der Evolutionstheorie und phylogenetischer Rekonstruktionen. - Acta Biotheoretica 26: 75-119.

Cherbonnier, G. 1978. Note sur deux empreintes d'holothuries fossiles du Trias moyen de la region de Tarragone (Espagne). - Thalassia Jugoslavica 12: 75-79.

Clark, H. L. 1898. Synapta vivipara: a contribution to the morphology of echinoderms. - Boston Society of Natural History, Memoirs 5: 53-88.

- 1907. The apodous holothurians. A monograph of the Synaptidae and Molpadiidae. - Smithsonian Contributions to Knowledge 35: $1-231$.

David, B. \& Mooi, R. 1996. Embryology supports a new theory of skeletal homologies for the phylum Echinodermata. - Comptes Rendues de l'Academie des Sciences de Paris, Sciences de la Vie 319: 577-584.

- 1998. Major events in the evolution of echinoderms viewed by the light of embryology. In R. Mooi \& M. Telford (eds). Echinoderms: 21-28. Balkema, Rotterdam.

Dawydoff, C. 1948. Embryologie des échinodermes. In P. P. Grassé (ed.). Traité de Zoologie. Anatomie, Systématique, Biologie 11: 277-363. Masson, Paris.

Deflandre-Rigaud, M. 1962. Contribution à la connaissance des sclérites d'holothuroides fossiles. - Mémoires du Muséum d'Histoire Naturelle de Paris, N. S. 11: 123 pp.

Edlinger, K. 1994. Ontogenetische Mechanismen in Beziehung zur Evolution. In W. F. Gutmann, D. Mollenhauer \& D. S. Peters (eds). Morphologie und Evolution. Senckenberg-Buch 70: 365-384. W. Kramer, Frankfurt/M.

Edwards, C. L. 1909. The development of Holothuria florida$n a$ Pourtalés with special references to the ambulacral appendages. - Journal of Morphology 20: 211-230.

Fell, H. B. 1965. The early evolution of the Echinozoa. Harvard University, Museum of Comparative Zoology, Breviora 219: 1-17.

Frizzell, D. L. \& Exline, H. 1955. Monograph of fossil holothurian sclerites. - Bulletin of the Missouri University School of Mines and Metallurgy, Technical Series 89: 204 pp.

- 1966. Holothuroidea - fossil record. In R. C. Moore (ed.). Treatise on Invertebrate Paleontology, U 3 (2): 646-672. Geological Soiety of America, Boulder and Lawrence.

Gilliland, P. M. 1993. The skeletal morphology, systematics and evolutionary history of holothurians. - Special Papers on Palaeontology 47: $147 \mathrm{pp}$.

Grasshoff, M. \& Gudo, M. 2001. The Evolution of Animals. -16 pp. (2. ed.). Senckenberg, Frankfurt / M.

Gudo, M. 2001. Konstruktion, Evolution und riffbildendes Potential der rugosen Korallen. - Courier Forschungsinstitut Senckenberg 228: $153 \mathrm{pp}$.

Gutmann, W. F. 1994. Evolution von Konstruktionen: Die Frankfurter Theorie. In W. F. Gutmann, D. Mollenhauer \& D. S. Peters (eds). Morphologie und Evolution. Senckenberg-Buch 70: 317-338. W. Kramer, Frankfurt / M.

- 1995. Die Evolution hydraulischer Konstruktionen: Organismische Wandlung statt altdarwinistischer Anpassung. - Senckenberg-Buch 65: 220 pp. Kramer, Frankfurt / M.

Haude, R. 1992. Fossil holothurians: Sclerite aggregates as 'good' species. In L. Scalera-Liaci \& C. Canicatti (eds). Echinoderm Research: 29-33. Balkema, Rotterdam.

- 1994. Fossil holothurians: Constructional morphology of the sea cucumber and the origin of the calcareous ring. In B. David, A. Guille, J. P. Feral, \& M. Roux (eds). Echinoderms through Time: 517-522. Balkema, Rotterdam. 
- 1995a. Die Holothurien-Konstruktion: Evolutionsmodell und ältester Fossilbericht. - Neues Jahrbuch für Geologie und Paläontologie, Abhandlungen 195: 181-198.

- 1995b. Echinodermen aus dem Unter-Devon der argentinischen Präkordillere. - Neues Jahrbuch für Geologie und Paläontologie, Abhandlungen 197: 37-86.

- 1997. Nudicorona, eine devonische Holothuric. - Fossilien 1: 50-57.

Haude, R. \& Langenstrassen, F. 1976. Rotasaccus dentifer n. g., n. sp., ein devonischer Ophiocistioide (Echinodermata) mit 'holothuroiden' Wandskleriten und 'echinoidem' Kauapparat. - Paläontologische Zeitschrift 50: 130-150.

Hotchkiss, F. H. C. 1995. Loven's law and adult ray homologies in echinoids, ophiuroids, edrioasteroids, and an ophiocistioid (Echinodermata: Eleutherozoa). - Proceedings of the Biological Society of Washington 108: $401-435$.

- 1998. A 'rays-as-appendages' model for the origin of pentamerism in echinoderms. - Paleobiology 24: 200-214.

Hyman, L. H. 1955. The Invertebrates: Echinodermata. The coelomate Bilateria IV: 763 pp. McGraw-Hill, New York.

Jackson, R. T. 1912. Phylogeny of the Echini, with a revision of Paleozoic species. - Memoirs of the Boston Society of Natural History 7: 1-490.

Janich, P. \& Weingarten, M. 1999. Wissenschaftstheorie der Biologie. Methodische Wissenschaftstheorie und die $\mathrm{Be}$ gründung der Wissenschaften. - 317 pp. W. Fink, München.

Jell, P. A. 1983. Early Devonian echinoderms from Victoria (Rhombifera, Blastoidea and Ophiocistioidea). - Memoirs of the Association of Australasian Palaeontologists 1: $209-235$

Kerr, A. M. 2001. Phylogeny of apodan holothurians (Echinodermata) inferred from morphology. - Zoological Journal of the Linnean Society 133: $53-62$.

Kerr, A. M. \& Kim, J. 1999. Bi-penta-bidecaradial symmetry: a review of evolutionary and developmental trends in Holothuroidea (Echinodermata). - Journal of Experimental Zoology 285: 93-103.

- 2001. Phylogeny of Holothuroidea (Echinodermata) inferred from morphology. - Zoological Journal of the Linnean Society 133: $63-81$.

Kutscher, F. \& Sieverts-Doreck, H. 1977. Uber Holothurien im Hunsrückschiefer, - Geologisches Jahrbuch Hessen 105: $47-55$

Lehmann, W. M. 1958. Eine Holothurie zusammen mit Palaenectria devonica und einem Brachiopoden in den unterdevonischen Dachschiefern des Hunsrücks durch Röntgenstrahlen entdeckt. -- Notizblatt des hessischen Landesamtes für Bodenforschung 86: 81-86.

Littlewood, D. T. J., Smith, A. B., Clough, K. H. \& Emson, R. H. 1997. The interrelationships of the echinoderm classes: morphological and molecular evidence. - Biological Journal of the Linnean Society 61: 409-438.

Ludwig, H. 1889-1892. Die Seewalzen. In H. G. Bronn's (ed.) Klassen und Ordnungen des Thier-Reichs, wissenschaftlich dargestellt in Wort und Bild, 2(3), H. Ludwig: Echinodermen (Stachelhäuter) 1: 1-460. C. F. Winter, Leipzig.

- 1891. Ankyroderma musculus (Risso), eine Molpadiide des Mittelmeeres, nebst Bemerkungen zur Phylogenie und Systematik der Holothurien. - Zeitschrift für Wissenschaftliche Zoologie 51: 569-612.

MacBride, E. W. \& Spencer, W. K. 1938. Two new Echinoidea, Aulechinus and Ectinechinus, and an adult plated holothurian, Eothuria, from the Upper Ordovician of Girvan, Scotland. - Royal Society London, Philosophical Transactions B 229: $91-136$.

Mooi, R. \& David, B. 1997. Skeletal homologies of echinoderms. In J. A. Waters \& C. G. Maples (eds). Geobiology of Echinoderms The Paleontology Society Papers 3: $305-335$.
Mooi, R. \& David, B. 1998. Evolution within a bizarre phylum: homologies of the first echinoderms. - American Zoologist 38: 965-974.

Mooi, R., David, B. \& Marchand, D. 1994. Echinoderm skeletal homologies: classical morphology meets modern phylogenetics. In B. David, A. Guille, J. P. Feral \& M. Roux (eds). Echinoderms through Time: 87-95. Balkema, Rotterdam.

Pawson, D. L. 1966. Phylogeny and evolution of holothuroids. In R. C. Moore (ed.). Treatise on Invertebrate $\mathrm{Pa}$ leontology, U 3 (2): 641-646.

Prokop, R. 1993. First find of the undoubted skeletal elements of holothurians in the Devonian of Czech Republic. - Casopis Narodniho Muzea, Rada prirodovedna 161: $45-46$.

Reich, M. 1999. Ordovizische und silurische Holothurien (Echinodermata). - Greifswalder Geowissenschaftliche Beiträge 6: $479-488$.

Runnström, S. 1928. Über die Entwicklung von Leptosynapta inhaerens (O. Fr. Müller). - Bergens Museums Årbok 1927, Naturvidenskapelig Rekke 1: 1-80.

Seilacher, A. 1961. Holothurien im Hunsrückschiefer (UnterDevon). - Notizblatt des hessischen Landesamts für Bodenforschung 89: 66-72.

- 1994. Candle wax shells, morphodynamics and the Cambrian explosion. - Acta Palaeontologica Polonica 38: 273-280.

Selenka, E. 1876. Zur Entwickelung der Holothurien (Holothuria tubulosa und Cucumaria doliolum). - Zeitschrift für Wissenschaftliche Zoologie 27: $155-178$.

Semon, R. 1888. Die Entwicklung der Synapta digitata und ihre Bedeutung für die Phylogenie der Echinodermen. Jenaische Zeitschrift für Naturwissenschaften 22: 175-309.

Smiley, S. 1986. Metamorphosis of Stichopus californicus (Echinodermata: Holothuroidea) and its phylogenetic implications. - Biological Bulletin 171: $611-631$.

- 1988. The phylogenetic relationships of holothurians: a cladistic analysis of the extant echinoderm classes. In $\mathrm{C}$. R. C. Paul \& A. B. Smith (eds). Echinoderm Phylogeny and Evolutionary Biology: 69-84. Clarendon Press, Oxford.

- 1994. Holothuroidea. In F. W. Harrison (ed.). Microscopic Anatomy of Invertebrates 14: 401-471. Wiley, New York.

Smith, A. B. 1988. Fossil evidence for the relationships of extant echinoderm classes and their times of divergence. In C. R. C. Paul \& A. B. Smith (eds). Echinoderm Phylogeny and Evolutionary Biology: 85--97. Clarendon Press, Oxford.

- 1997. Echinoderm larvae and phylogeny. - Annual Review of Ecology and Systematics 28: 219-241.

Smith, A. B. \& Gallemí, J. 1991. Middle Triassic holothurians from Northem Spain. - Palaeontology 34: 49-76.

Sroka, S. D. 1988. Preliminary studies on a complete fossil holothurian from the Middle Pennsylvanian Francis Creek Shale of Illinois. In R. D. Burke, P. V. Mladenov, P. Lambert \& R. L. Parsley. Echinoderm Biology: 159-160. Balkema, Rotterdam.

Strathmann, R. R. 1975. Limitations on diversity of forms: branching of ambulacral systems of echinoderms. - The American Naturalist 109: 177-190.

Thomson, K. S. 1992. Macroevolution: The morphological problem. - The American Zoologist 32: 106-112.

Ubaghs, G. 1966. Ophiocistioids. In R. C. Moore (ed.). Treatise on Invertebrate Paleontology, U1: 174-188. Geological Society of America, Lawrence.

Wray, G. A. \& Lowe, C. J. 2000. Developmental regulatory genes and echinoderm evolution. - Systematic Biology 49: $151-174$. 


\section{Appendix: Preliminary description of two new holothurian taxa}

The body fossils mentioned above are part of two more extensive investigations on Argentinan and German echinoderm lagerstaetten. The types will be made available after publication, placed in the collections of the Palaeontological Museum of the University of Córdoba, Argentina (PMCA), and the Geoscience Center at Göttingen (GZG).

For the time being, the systematic position of the two genera is left open for following reasons: (i) Recent holothurian systematics rely almost totally on unfossilizable soft body structures; (ii) well known echinoderm groups had either disappeared at the end of the Palaeozoic, or higher level Mesozoic to Recent taxa are classified as quite different from their Palaeozoic relatives; (iii) a large-plate body wall skeleton as most typical in some Recent dendrochirotids is argued as secondary by arguments of constructional morphology, but it may also have been achieved several times in distinct evolutionary lines.

\section{Prokrustia n. gen.}

Type species: Prokrustia tabulifera n. gen., n. sp.

Name: After the great inn-keeper (with special service) Prokrustes in Greek mythology.

Diagnosis: Relatively very large, sausage-like form with oral and anal openings terminal, body wall heavily skeletonized, with mostly large, rather thick and perforated, imbricating plates of more or less elliptical outline. Mostly about 3-4 (podial?) pores irregularly distributed on the plates around the body, a few plates with slit-like perforations. Stereomic structure on inner surface of plates typically wide-spaced, becoming small-porous in marginal area.

Remarks: The hitherto only known Palaeozoic body fossils with plated wall skeletons are very small: one (still unnamed) incomplete specimen from the ?Pridolian (Gilliland 1993), and several specimens (Andenothyone) from the Emsian (Haude 1995b). In the Pridolian specimen, the presence of perforated plates was said to be probable; in the obviously quite similar Andenothyone, however, the plates are not perforated. Both forms preliminarily had been included into the dendrochirotids.

The pores in Prokrustia could have served for metacoelic protrusions with respiratory function comparable to papulae in asteroids. It is preferred, here to interpret them as conventional holothurian hydrocoelic structures, corresponding to those in the Triassic dendrochirotid Monilipsolus (Smith \& Gallemí 1991), i.e. as canals of unskeletonized podia (with respiratory potential).

\section{Prokrustia tabulifera n. gen., n. sp.}

Plate 1: 1-3; Fig. 4A

Name: tabula (lat.) - plate, ferre (lat.) - to carry.

Holotype: Specimen in Plate 1: 1 (latex cast of PMCAH1a, b).

Type locality and horizon: Argentinan Precordillera, about $9 \mathrm{~km}$ to the SW of Jachal (Prov. San Juán), in the Lower Devonian Talacasto Formation.

Paratypes: PMCA-H2, 3.

Diagnosis: As for the genus.

Description: Preservation of complete specimens as external and internal molds in siltstone. Body form sausage-like, cross-section probably circular, but biostratinomically somewhat flattened by compaction, large size (length/diameter: up to $10 \mathrm{~cm} / 2 \mathrm{~cm}$, or shorter and thicker). U-like curvature of specimens probably not found in life. "Anterior" and "posterior" hitherto not definable, but oral and anal openings terminal. Calcareous ring elements still not observed.

Body wall skeleton strong, of large and rather thick rectangular-rounded plates (max. diameter about $7 \mathrm{~mm}$ ), with smaller plates in-between. Many (if not most) plates (structures not always preserved on molds) with 1-6, mostly 3-4 small round pores of slightly differing diameter, distribution of pores quite irregular, occasional plate with a small marginal lobe as still incomplete pore, some plates with a large round pore, few plates with 1-4 slit-like perforations near to the margin, occasionally radially arranged. No preferred serial orientation of pores along the body wall.

\section{Podolepithuria n. gen.}

Type species: Podolepithuria walliseri n. gen., n. sp.

Na me: podion (gr.) - small foot, lepis (gr.) - scale.

Diagnosis: Body cucumber-shaped, with podia distributed all around. Body wall and podia densely skeletonized with small imbricating sclerites. Position of mouth at or near one end of the body. Skeletal plates of body wall mostly convexellipsoidal, in part with relatively wide-spaced stereomic perforation. Scale-like elements of the podia much smaller, some distally with tiny denticles.

Remarks: Holothurian body fossils with skeletonized podia all around the body were hitherto unknown from the Palaeozoic except some scleritomes (Boczarowski 2001) which, however, are assigned to Palaeocucumaria (i.e. 


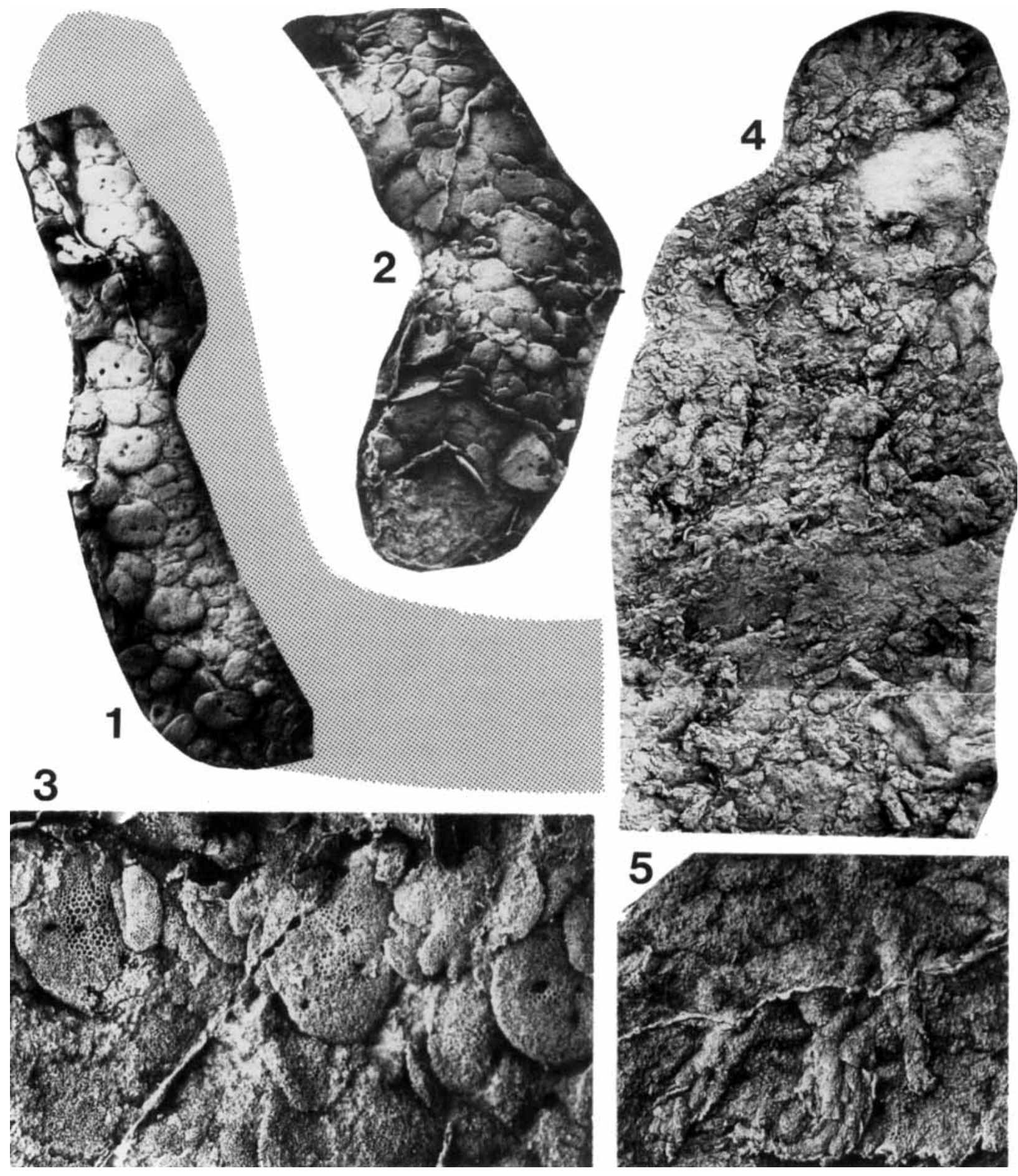

Plate 1. 1-3. Prokrustia tabulifera n. gen., n. sp. - 1. Part of body fossil (shadowed area tracing preserved internal mold), skeletal plates with (?)podial perforations (holotype, PMCA-H1a, latex cast of external mold; $\times 1.8$ ). 2. Body fossil with lower end bent upwards thus preserving almost circular outline of cross section (PMCA-H2, latex cast of external mold; $\times$ 1.8). 3. Detail of inner surface of body wall plates in the holotype showing internal openings of perforations and typical honeycomb stereomic structure (PMCA-H1b, latex cast of part of internal mold; $\times 5$ ). 4-5. Podolepithuria walliseri $\mathrm{n}$. gen., $\mathrm{n}$. sp. - 4. Part of body fossil with many skeletonized podia, wall skeleton slightly disarranged, ossicles scattered about in the marginal area (holotype, GZG 1123-1, latex cast of external mold; $\times 2.6$ ). 5. Scaled podia of another body fossil, in the body wall some elements visible with relatively large-spaced stereomic network (GZG 1123-2, latex cast of external mold; $\times 10$ ).

typically with adoral podia/tentacles, only). The only other pedate body fossils are from the Triassic (Cherbonnier 1978, Smith \& Gallemí 1991). However, in these forms the podia (or papillae) are not skeletonized with imbricating scales but only densely spiculed. They either vary in size and are irregularly distributed around the body or they are differentiated in the lateral and ventral areas, and arranged in longitudinal rows. 


\section{Podolepithuria walliseri n. gen., n. sp.}

Plate 1: 4, 5; Fig. 4B

Name: For Otto H. Walliser, retired head of the Institute and Museum of Geology and Palaeontology (former name) at Göttingen University.

Holoty pe: Specimen in Plate 1: 4 (latex cast of GZG 1123-1).

Type locality and horizon: Road cut into highway A 45 at Drolshagen / Wegeringhausen, in the Lower Givetian Wiedenest Formation (Middle Devonian).

Paratypes: Parts of almost completely fossilized specimens preserved as external molds, GZG 1123-2, 1123-3.

\section{Diagnosis: As for the genus.}

Description: Flattened (collapsed) bodies of cucumber-like form (length/width: holotype $>7 / 2.5 \mathrm{~cm}$ ), outlines obscured by rather closely neighbouring podia all around. Skeletal elements more or less disarranged, ends of body rounded, position of mouth and anus hitherto not known, but probably terminal. Calcareous ring not observed.

Body wall well skeletonized, mostly with small more or less ellipsoidal, bilaterally-convex, imbricating ossicles, and masses of (?porous) granules which may totally cover undisturbed parts of the wall. Surface of wall ossicles typically with a wide-spaced stereomic lattice work in the middle part; some obviously larger, flat elements of unknown outlines locally visible, with a honeycombed stereomic structure.

Podia showing no radial arrangement in the aboral part of the body, probably differing only slightly in size by contractional states (length $>5 \mathrm{~mm}$ ), with more or less pointed distal end, others with a somewhat flattened to concave end, probably resulting from contraction with stronger imbrication of scale-like sclerites; these probably all of more or less same outlines, rounded to elongate-elliptical, much smaller than body wall ossicles, some with about 1-2 tiny processes near to the distal margin. Stereomic structure very narrow-porous.

Remarks: Most of the typical body wall platelets would correspond to the morphotype "Mortensenites" (Haude 1992: fig. 1A). According to the definition given by Frizzel \& Exline (1955: 90), this form would include all multilayered sclerites regardless of outline. However, such a definition would be of no nomenclatoric use here since even the Jurassic type species is polygonal.

Some of the wall and podial ossicles of Podolepithuria may correspond to elements of scleritome taxa described by Boczarowski (2001), e.g. to scales of Palaeocucumaria ancile, and of $P$. delicata; or to ossicles with widely spaced stereomic pores in Palaeohemioedema cognata and Eocaudina plaga.

However, there are some significant differences: in Podolepithuria, sclerites lack the typical less poriferous central axis of tentacular scales, or distally oriented pointed processes are not part of the distal margin. The other similarities with sclerites of the mentioned taxa would not be very characteristic if they were not part of associations forming characteristic scleritomes.

The special quality of Podolepithuria walliseri n. sp. could also be demonstrated by a general argument: The typical masses of more or less ellipsoidal body wall ossicles should have been found associated with the mentioned taxa of the Holy Cross region; but they are wanting. On the other hand, these arguments may support the (principally most problematical) assignment of the scleritome species ancile and delicata to Palaeocucumaria, which in contrast to the totally pedate Podolepithuria, has only more or less adorally located podia. 